\title{
Development of free amino acids in Appenzeller, Emmentaler, Gruyère, Raclette, Sbrinz and Tilsiter cheese
}

\author{
U Bütikofer, D Fuchs
}

Swiss Federal Dairy Research Station, Liebefeld, 3003 Berne, Switzerland

\begin{abstract}
Summary - The free amino acid development of Appenzeller, Emmentaler, Gruyère, Raclette, Sbrinz and Tilsiter cheese is described. During the first five months of cheese ripening, the total amount of the free amino acids increases by $140-290 \mathrm{mg} \mathrm{kg}^{-1}$ per day. Gruyère shows the highest increase for 15 amino acids, Appenzeller for valine, methionine, phenylalanine and ornithine, Raclette for $\alpha$ - and $\gamma$-amino butyric acid, Emmentaler for alanine and Sbrinz for arginine. High quality cheese shows higher relative amounts of aspartic acid, asparagine and arginine and lower relative amounts of glycine, alanine, valine, methionine and isoleucine. The significant differences for Emmentaler were reversed for asparagine, alanine and methionine.
\end{abstract}

cheese / Appenzeller / Emmentaler / Gruyère / Raclette / Sbrinz / Tilsiter / free amino acid

Résumé - Développement des acides aminés libres dans les fromages appenzell, emmental, gruyère, raclette, sbrinz et tilsit. Le présent travail traite de la formation des acides aminés libres dans des fromages de type Appenzell, emmental, gruyère, raclette, sbrinz et tilsit. Durant les 5 premiers mois d'affinage, la quantité totale des acides aminés libres crôt à raison d'environ 140 à $290 \mathrm{mg}$ par $\mathrm{kg}$ et par jour. Le gruyère montre la plus forte augmentation pour 15 acides aminés, l'appenzell pour la valine, la méthionine, la phénylalanine et l'ornithine, la raclette pour les acides $\alpha$ - et $\gamma$-amino butyriques, l'emmental pour l'alanine et le sbrinz pour l'arginine. Les fromages de bonne qualité contiennent des concentrations relatives élevées d'acide aspartique, d'asparagine et d'arginine et des concentrations plus basses de glycine, d'alanine, de valine, de méthionine et d' isoleucine. L'effet est inverse dans l'emmental pour l'asparagine, l'alanine et la méthionine.

fromage / appenzell / emmental / gruyère / raclette / sbrinz / tilsit / acide aminé libre

Oral communication at the IDF Symposium 'Ripening and Quality of Cheeses', Besançon, France, February 26-28, 1996. 


\section{INTRODUCTION}

Protein breakdown of caseins during cheese ripening is very important in the development of the texture and background flavour of most cheese varieties (Desmazeaud and Gripon, 1977; Rank et al, 1985; Fox, 1989). Due to the action of rennet, peptidases from starter bacteria, secondary microflora and indigenous milk enzymes, peptides and amino acids are liberated (Langsrud et al, 1977; Klostermeyer and Krause, 1992; Barcina et al, 1995; Exterkate and Alting, 1995). The released amino acids are precursors for several amino acids not present in caseins (glutamic acid for $\alpha$-and $\gamma$-amino butyric acid, arginine for ornithine and citrulline), biogenic amines (Leuthardt, 1977) and for volatile flavour compounds (eg, aldehydes, ketones, short-chain fatty acids and alcohols (Urbach, 1993).

For determination of free amino acids, different analytical methods have been developed. Moore and Stein (1951) first published a report on ion exchange chromatographic separation of amino acids. In the last 20 years reversed phase high-performance liquid chromatography (HPLC) methods with precolumn derivatisation became popular (Einarsson, 1985; Schuster, 1988; Fürst et al, 1990). Quantitative determination of free amino acids in cheese has been reported in different articles (Polo and Ramos, 1985; Resmini et al, 1985; Griffith and Hammond, 1989; de Llano et al, 1991; Lavanchy and Sieber, 1993; Resmini et al, 1993; Engels and Visser, 1994; Bütikofer, 1996).

The present work describes the content of the individual free amino acids during ripening of six hard and semi-hard cheese varieties. Linear regression was used to describe the relationship between free amino acid content and cheese age.

\section{MATERIALS AND METHODS}

Five cheese varieties (Appenzeller, Gruyère, Raclette, Sbrinz and Tilsiter) were investigated in the course of their ripening. The sample selec- tion was described in the following publications: Sbrinz (Sollberger et al, 1992), Gruyère (Steffen et al, 1980), 'Walliser Raclette' (Schär et al, 1992), Appenzeller (Steffen et al, 1993a) and Tilsiter made from raw milk (Steffen et al, 1993b). Additional results were obtained in several comparisons of good quality cheese and cheese with late fermentation: Appenzeller (Steffen et al, 1981b), Emmentaler (Lavanchy et al, 1979), Gruyère (Steffen et al, 1992), Sbrinz (Steffen et al, 1981a) and Tilsiter made from raw milk (Steffen et al, 1982).

The determination of free amino acids was performed on an ion exchange amino acid analyser with postcolumn ninhydrin derivatisation and detection at 570 and $440 \mathrm{~nm}$ for primary and secondary amino acids according to the procedure of Lavanchy and Bühlmann (1983).

\section{Statistical analysis}

Linear regression, Kruskal-Wallis one-way anal$y$ sis of variance and full factorial analysis of variance (MANOVA) calculations were carried out using the SYSTAT statistical software package (1992).

\section{RESULTS AND DISCUSSION}

In total, 22 different free amino acids could be quantified in more than one thousand cheese samples of these six cheese varieties.

\section{Development of individual free amino acids in good quality cheese}

The increase of individual free amino acids of good quality cheese during the first five ripening months can be fitted using a linear regression. The amount of each free amino acid can be calculated by the formula:

Amount of free amino acid $=$ cheese age $x$ slope + intercept

Gruyère shows the highest slope for aspartic acid, threonine, serine, asparagine, glutamic 
Table I. Free amino acids in six cheese varieties: linear regression slope $\left(\mathrm{mg} \mathrm{kg}^{-1} \mathrm{day}^{-1}\right)$; one to 150 days.

Acides aminés libres dans six sortes de fromages : pente de la régression linéaire.

Cheese variety Asp Thr Ser Asn Glu Gln Pro Gly Ala Cit $\alpha$-AbaVal Met Ile Leu Tyr Phe $\gamma$-Aba Orn Lys His Arg

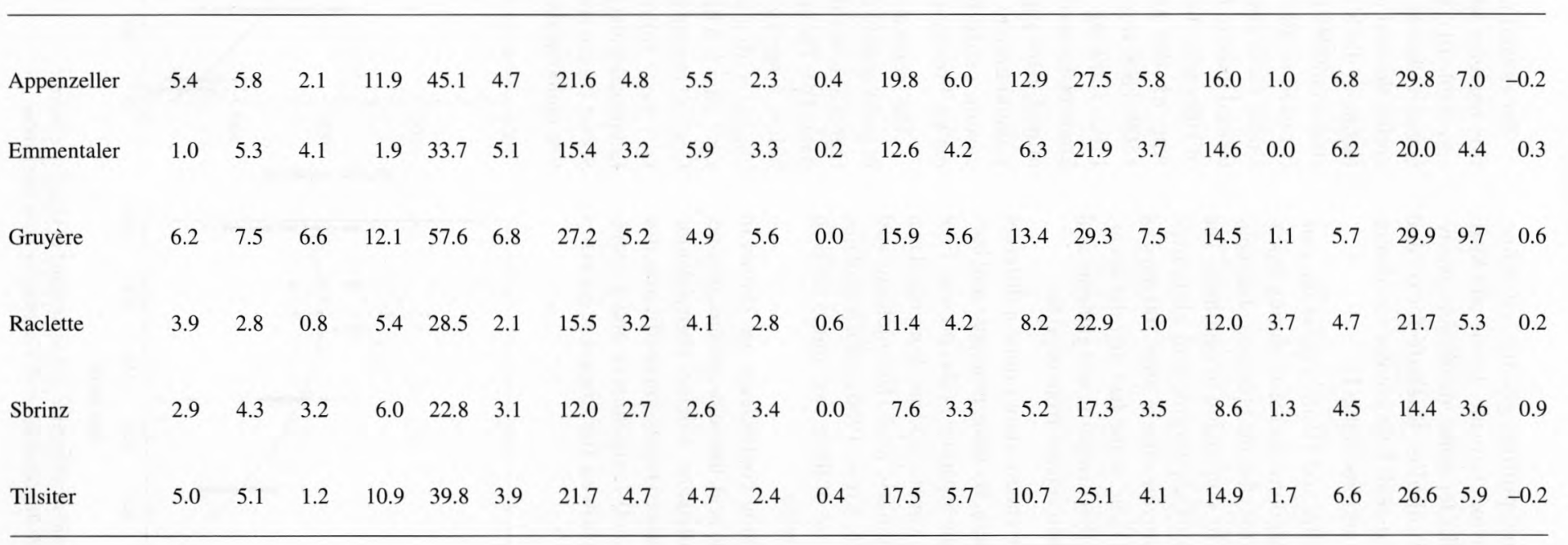


acid, glutamine, proline, glycine, citrulline, isoleucine, leucine, tyrosine, lysine and histidine, Appenzeller for valine, methionine, phenylalanine and ornithine, Raclette for $\alpha$ - and $\gamma$-amino butyric acid, Emmentaler for alanine and Sbrinz for arginine (table I).

In Appenzeller and Tilsiter cheese the concentration of arginine decreases during ripening, which indicates that the liberation of arginine is slower than its conversion to ornithine. The concentration of asparagine and glutamine decreases in Gruyère cheese after 200 days of ripening (fig 1) due to the fact that the decarboxylation reaction to aspartic and glutamic acid is faster than their release from peptides.

Emmentaler cheese shows quite a different amino acid pattern. By using propionic acid bacteria, the enzyme aspartase is also present. Free asparagine and aspartic acid are deaminated in a first step to fumaric acid (Brendehaug and Langsrud, 1985; Crow, 1986), which explains the slow increase of these two amino acids in Emmentaler cheese.

The regression coefficients are shown in table II. Aspartic acid, threonine, proline, glycine, methionine, isoleucine, leucine, phenylalanine and histidine showed regression coefficients that were higher than 0.7 ; arginine, $\alpha$ - and $\gamma$-amino butyric acid showed the lowest regression coefficients.

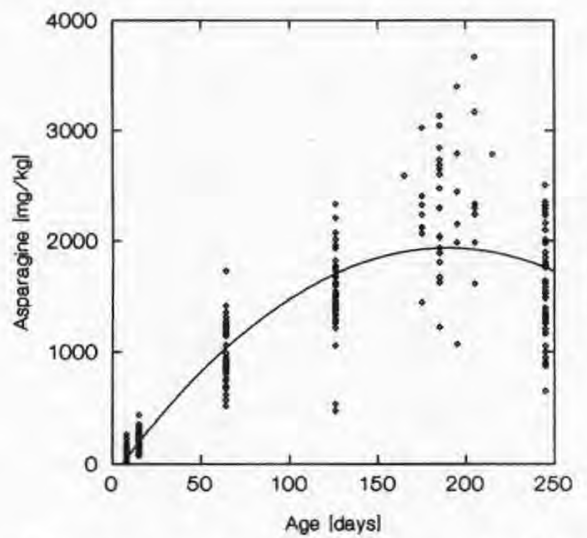

For several amino acids, the linear regression intercept was significantly different from zero (table III). This can be related to the accelerated release or conversion of free amino acids during the first day of ripening. During manufacture of these six cheese varieties, rennet and starter cultures are added and the temperature is raised to $40-57^{\circ} \mathrm{C}$ for more than $30 \mathrm{~min}$. Under these conditions, free amino acids are formed three to five times faster. After one day of ripening, the sum of free amino acids in Appenzeller and Tilsiter was on average $1500-1600 \mathrm{mg} \mathrm{kg}^{-1}$, in Raclette and Sbrinz $1100-1200 \mathrm{mg} \mathrm{kg}^{-1}$ (the free amino acids in Emmentaler and Gruyère cheese were not determined after one day). Even ornithine and $\gamma$-amino butyric acid, which are not present in casein, could be found at levels of 20-80 $\mathrm{mg} \mathrm{kg}^{-1}$ in one-day-old cheese.

The increase in the sum of free amino acids in good quality cheese can be fitted to a linear regression within the first 150 ripening days (table IV). The standard deviation of the slope is below $8 \mathrm{mg} \mathrm{kg}^{-1}$ day $^{-1}$, except for Raclette cheese with a standard deviation of $14 \mathrm{mg}$ $\mathrm{kg}^{-1}$ day $^{-1}$. The sum of free amino acids in Gruyère cheese increases by more than $290 \mathrm{mg}$ $\mathrm{kg}^{-1}$ day $^{-1}$ followed by Appenzeller, Tilsiter, Emmentaler and Raclette cheese. The extra-hard Sbrinz cheese shows the slowest increase of the free amino acids, with only $139 \mathrm{mg} \mathrm{kg}^{-1}$ day-1 $^{-1}$.

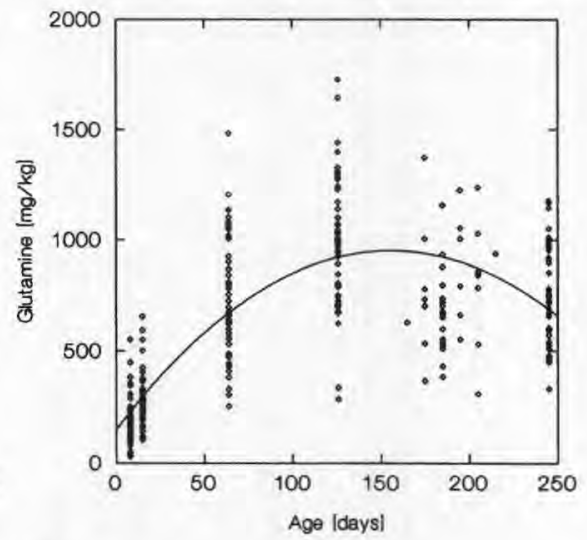

Fig 1. Development of glutamine and asparagine in Gruyère cheese.

Développement de la glutamine et de l'aspargine dans le gruyère. 
Table II. Free amino acids in six cheese varieties: regression coefficient.

Acides aminés libres dans six sortes de fromages : coefficient de régression.

\begin{tabular}{|c|c|c|c|c|c|c|c|c|c|c|c|c|c|c|c|c|c|c|c|c|c|c|}
\hline Cheese variety & Asp & $T h r$ & Ser & Asn & Glu & Gln & Pro & Gly & Ala & Cit & $\alpha-A b a$ & Val & Met & Ile & Leu & $T y r$ & Phe & $\gamma-A b a$ & Orn & Lys & His & Arg \\
\hline Appenzeller & 0.87 & 0.89 & 0.56 & 0.79 & 0.94 & 0.57 & 0.93 & 0.90 & 0.79 & 0.72 & 0.60 & 0.93 & 0.94 & 0.90 & 0.95 & 0.87 & 0.94 & 0.15 & 0.82 & 0.92 & 0.89 & 0.19 \\
\hline Emmentaler & 0.86 & 0.92 & 0.95 & 0.37 & 0.93 & 0.87 & 0.91 & 0.91 & 0.96 & 0.81 & 0.16 & 0.94 & 0.95 & 0.88 & 0.97 & 0.83 & 0.96 & & 0.95 & 0.94 & 0.83 & 0.26 \\
\hline Gruyère & 0.78 & 0.76 & 0.70 & 0.86 & 0.88 & 0.67 & 0.87 & 0.91 & 0.67 & 0.92 & & 0.77 & 0.78 & 0.83 & 0.80 & 0.76 & 0.85 & 0.06 & 0.61 & 0.70 & 0.85 & 0.02 \\
\hline Raclette & 0.82 & 0.86 & 0.40 & 0.90 & 0.66 & 0.55 & 0.84 & 0.83 & 0.84 & 0.60 & 0.41 & 0.79 & 0.83 & 0.78 & 0.91 & 0.24 & 0.91 & 0.47 & 0.57 & 0.81 & 0.71 & 0.19 \\
\hline Sbrinz & 0.63 & 0.83 & 0.77 & 0.89 & 0.80 & 0.39 & 0.73 & 0.83 & 0.47 & 0.83 & 0.03 & 0.68 & 0.83 & 0.73 & 0.89 & 0.74 & 0.89 & 0.48 & 0.70 & 0.62 & 0.74 & 0.52 \\
\hline Tilsiter & 0.86 & 0.91 & 0.18 & 0.80 & 0.92 & 0.50 & 0.91 & 0.90 & 0.76 & 0.68 & 0.52 & 0.91 & 0.94 & 0.89 & 0.93 & 0.79 & 0.93 & 0.61 & 0.82 & 0.94 & 0.86 & 0.10 \\
\hline
\end{tabular}


Table III. Free amino acids in six cheese varieties: linear regression intercept ( $\left.\mathrm{mg} \mathrm{kg}^{-1}\right)$ (only if significantly different from 0 ).

Acides aminés libres dans six sortes de fromages : ordonnée à l'origine de la régression linéaire.

\begin{tabular}{|c|c|c|c|c|c|c|c|c|c|c|c|c|c|c|c|c|c|c|c|c|c|c|}
\hline Cheese variety & Asp & $T h r$ & Ser & Asn & Glu & Gln & Pro & Gly & Ala & Cit & $\alpha-A b a$ & Val & Met & Ile & Leu & Tyr & Phe & $\gamma-A b a$ & Orn & Lys & His & Arg \\
\hline Appenzeller & & & & & & 121 & & & 82 & & & & & & & & & 66 & 134 & & & 26 \\
\hline Gruyère & & 65 & 56 & 57 & & 191 & & & 181 & & & 92 & 61 & & 315 & 86 & 102 & 108 & 139 & 458 & & 54 \\
\hline Sbrinz & & & & & & 63 & & & 82 & & & 87 & & & & 52 & & 89 & 184 & & & \\
\hline Tilsiter & & & 55 & & & 158 & & & 89 & & & & & & & & & 114 & & & & 51 \\
\hline
\end{tabular}


Table IV. Linear regression of the sum of 22 amino acids of six different cheese varieties aged one to 150 days.

Régression linéaire de la somme des acides aminés libres des six variétés de fromage de un à 150 jours.

\begin{tabular}{lcccc}
\hline Cheese variety & $\mathrm{n}$ & Slope & $S D_{\text {slope }}$ & $\mathrm{r}$ \\
\hline Appenzeller & 85 & 245 & 7 & 0.969 \\
Emmentaler & 58 & 173 & 6 & 0.971 \\
Gruyère & 184 & 293 & 7 & 0.950 \\
Raclette & 29 & 169 & 14 & 0.919 \\
Sbrinz & 85 & 139 & 6 & 0.920 \\
Tilsiter & 94 & 222 & 6 & 0.964 \\
\hline
\end{tabular}

Slope: calculated linear regression slope $\left(\mathrm{mg} \mathrm{kg}^{-1}\right.$ day-1); $\mathrm{SD}_{\text {slope }}$ standard deviation of slope; $n$; number of determinations; $r$. regression coefficient.

Slope : pente de la régression linéaire $\left(\mathrm{mg} \mathrm{kg}^{-1}\right.$ jour $\left.{ }^{-1}\right) ; S D_{\text {slope }}$ :écart type de la pente de la régression linéaire ; $\mathrm{n}:$ nombre des déterminations; $\mathrm{r}$ : coefficient de régression.

\section{Comparison of good quality cheese and cheese with late fermentation}

The increase of free amino acids in cheese is normally higher in cheese with late fermentation than in good quality cheese (table V). Steffen et al (1979) defined cheese with late fermentation (due to $\mathrm{CO}_{2}$ production) by bad storage properties, increase in loaf height and asymmetrical eye formation during ripening at $10-13{ }^{\circ} \mathrm{C}$. Statistically significant differences can be found for Emmentaler, Gruyère and Tilsiter cheeses with late fermentation, where the sum of free amino acids is 38,19 and $18 \%$ higher.

To compare the free amino acid patterns of different cheese varieties, the original results were normalised by the following formula:

$$
\text { rel } x_{\mathrm{i}}=\frac{x_{\mathrm{i}}}{\sum x_{\mathrm{i}}} \times 100 \%
$$

where: $x_{\mathrm{i}}=$ absolute amount of an individual amino acid $\left(\mathrm{mg} \mathrm{kg}^{-1}\right)$; rel $x_{\mathrm{i}}=$ relative amount of individual amino acids $(\%) ; \sum x_{\mathrm{i}}=$ sum of the absolute amount of free amino acids $\left(\mathrm{mg} \mathrm{kg}^{-1}\right)$.

With the Kruskal-Wallis one-way analysis of variance, the following significant differences could be found: at least three good quality cheese varieties had higher relative amounts of aspartic acid, asparagine and arginine and lower of glycine, alanine, valine, methionine and isoleucine (table VI); the significant differences for Emmentaler cheese were reversed for asparagine, alanine and methionine.

\section{Application of multivariate ANOVA}

Resmini et al $(1985,1993)$ identified genuine Parmigiano-Reggiano and Grana Padano cheese by their free amino acid composition via a chemometric model. In the present work, the possibility of classification was tested on the 
Table V. Comparison of the sum of free amino acids of good quality cheese and cheese with late fermentation.

Comparaison de la somme des acides aminés libres des fromages de bonne et mauvaise qualités.

\begin{tabular}{|c|c|c|c|c|c|c|c|}
\hline \multirow{3}{*}{$\begin{array}{l}\text { Cheese } \\
\text { variety }\end{array}$} & \multicolumn{6}{|c|}{ Cheese quality } & \multirow{3}{*}{$\begin{array}{c}\text { Kruskal-Wallis } \\
\text { one-way } \\
\text { ANOVA }\end{array}$} \\
\hline & \multicolumn{3}{|c|}{$\begin{array}{c}\text { Bad } \\
\text { (late fermentation) }\end{array}$} & \multicolumn{3}{|c|}{ Good } & \\
\hline & $\mathrm{n}$ & Slope & $r^{2}$ & $\mathrm{n}$ & Slope & $r^{2}$ & \\
\hline Sbrinz & 52 & 132 & 0.955 & 49 & 125 & 0.939 & \\
\hline Emmentaler & 57 & 238 & 0.939 & 59 & 173 & 0.943 & * \\
\hline Gruyère & 49 & 237 & 0.980 & 43 & 201 & 0.954 & * \\
\hline Appenzeller & 61 & 255 & 0.959 & 59 & 252 & 0.958 & \\
\hline Tilsiter & 54 & 266 & 0.940 & 54 & 226 & 0.919 & * \\
\hline
\end{tabular}

Legend: see table IV; ANOVA: analysis of variance; * significantly different, $P<0.01$.

* Différence significative, $\mathrm{p}<0,01$.

Table VI. Comparison of the individual free amino acids of good quality cheese and cheese with late fermentation.

Comparaison des acides aminés libres des fromages de bonne et mauvaise qualité.

\begin{tabular}{|c|c|c|c|c|c|}
\hline Amino acid & $\begin{array}{c}\text { Tilsiter } \\
125-165^{\mathrm{a}} \\
108^{\mathrm{b}}\end{array}$ & $\begin{array}{c}\text { Appenzeller } \\
125-165^{\mathrm{a}} \\
120^{\mathrm{b}}\end{array}$ & $\begin{array}{c}\text { Gruyère } \\
165-235^{\mathrm{a}} \\
92^{\mathrm{b}}\end{array}$ & $\begin{array}{c}\text { Sbrinz } \\
285-375^{\mathrm{a}} \\
101^{\mathrm{b}}\end{array}$ & $\begin{array}{c}\text { Emmentaler } \\
105-165^{\mathrm{a}} \\
120^{\mathrm{b}}\end{array}$ \\
\hline Aspartic acid & ++ & ++ & ++ & + & \\
\hline Threonine & ++ & & & ++ & \\
\hline Serine & & & & & -- \\
\hline Asparagine & ++ & ++ & ++ & + & -- \\
\hline Glutaminc acid & & & - & & \\
\hline Glutamine & & ++ & + & & \\
\hline Proline & & & -- & & -- \\
\hline Glycine & -- & -- & -- & -- & -- \\
\hline Alanine & -- & & -- & -- & ++ \\
\hline Citrulline & & - & & & \\
\hline$\alpha$-Amino butyric acid & -- & -- & & & \\
\hline Valine & -- & & -- & -- & \\
\hline Methionine & - & -- & - & & + \\
\hline Isoleucine & -- & -- & -- & & -- \\
\hline Leucine & & & + & & ++ \\
\hline Tyrosine & & ++ & & & \\
\hline Phenylalanine & & & & & ++ \\
\hline$\gamma$-Amino butyric acid & -- & -- & & & \\
\hline Ornithine & ++ & & & -- & ++ \\
\hline Lysine & & -- & -- & & + \\
\hline Histidine & ++ & ++ & & & - \\
\hline Arginine & + & & ++ & ++ & \\
\hline
\end{tabular}

Relative amino acid concentration in good quality cheese: ++: high $P<0.01$; +: high $P<0.05 ;--$ : low $P<0.01$; - : low $P$ $<0.05$. a cheese age (days); ${ }^{b} n$ value.

Concentration relative des acides aminés dans les bons fromages : ++ : élevée, $\mathrm{p}<0,01 ;+;$ élevée, $\mathrm{p}<0,05 ;--;$ faible, $\mathrm{p}<0 ; 01 ;-:$ faible, $\mathrm{p}<0,05$, a Âge du fromage (jours); ${ }^{\mathrm{b}}$ valeur de $\mathrm{n}$. 
Table VII. Classification of different cheese varieties with multivariate analysis of variance of free amino acids.

Classification des différentes variétés de fromage selon l'analyse de variance multivariée.

$\begin{array}{lll}\text { Cheese variety } & \mathrm{n} & \begin{array}{l}\text { Correct } \\ \text { classification (\%) }\end{array}\end{array}$

$\begin{array}{lrr}\text { Emmentaler } & 116 & 97 \\ \text { Gruyère } & 320 & 93 \\ \text { Raclette } & 30 & 80 \\ \text { Sbrinz } & 254 & 93 \\ \text { Appenzeller } & 169 & 75 \\ \text { Tilsiter } & 158 & 70\end{array}$

relative amounts of free amino acid by multivariate ANOVA. The cheese varieties Emmentaler, Gruyère and Sbrinz could be correctly classified to more than $93 \%$ (table VII). The two cheese varieties Appenzeller and Tilsiter are very similar in texture and flavour, as manufacturing and ripening conditions are comparable. Therefore it is not surprising that they could only be correctly classified to $70-75 \%$. Because the production of Raclette cheese was artisanal and the production parameters were very different, the cheese could only be correctly classified to $80 \%$ by its amino acid pattern.

\section{FUTURE TRENDS}

Depending on the origin of the milk, cheese manufacturing parameters, indigenous microorganisms, added starter cultures and ripening conditions, specific free amino acid patterns may be used to characterise different cheese varieties. The production of cheese specialties with traditional manufacturing and informative labelling (AOP, or Appellation d'Origine Protégée) is expensive, and therefore requires protection against cheaper industrial imitation products (Linden and Chamba, 1994). Chemometric models (Resmini et al, 1985, 1993) and multivariate statistics help to define models for detecting falsification of cheese labelling.

\section{ACKNOWLEDGMENTS}

The authors thank JO Bosset and R Sieber for reviewing this manuscript.

\section{REFERENCES}

Barcina Y, Ibáñez FC, Ordoñez A (1995) Evolution of free amino acids during Idiazábal cheese ripening. Food Control 6, 161-164

Brendehaug J, Langsrud T (1985) Amino acid metabolism in propionibacteria: resting cells experiments with four strains. J Dairy Sci 68, 281-289

Bütikofer U (1996) Quantitative determination of free amino acids in cheese. Bull Int Dairy Fed (in press)

Crow VL (1986) Metabolism of aspartate by Propionibacterium freudenreichii subsp shermanii: effect on lactate fermentation. Appl Environ Microbiol $52,359-365$

de Llano DG, Polo MC, Ramos M, Martín-Alvarez P (1991) Free and total amino acids in the non-protein fraction of an artisanal blue cheese during ripening. Z Lebensm Unters Forsch 193, 529-532

Desmazeaud JJ, Gripon JC (1977) General mechanism of protein breakdown during cheese ripening. Milchwissenschaft 32, 731-734

Einarsson S (1985) Selective determination of secondary amino acids using precolumn derivatization with 9-fluorenylmethylchloroformate and reversed-phase high-performance liquid chromatography. J Chromatogr 348, 213-220

Engels WJM, Visser S (1994) Isolation and comparative characterization of components that contribute to the flavour of different types of cheese. Neth Milk Dairy J 48, 127-140

Exterkate FA, Alting AC (1995) The role of starter peptidases in the initial proteolytic events leading to amino acids in Gouda cheese. Int Dairy J 5, 15-28

Fox PF (1989) Proteolysis during cheese manufacture and ripening. I Dairy Sci 72, 1379-1400

Fürst P, Pollack L, Graser, TA, Godel H, Stehle P (1990) Appraisal of four pre-column derivatization methods for the high-performance liquid chromatographic determination of free amino acids in biological materials. J Chromatogr 499, 557-569

Griffith R, Hammond EG (1989) Generation of Swiss cheese flavour components by reaction of amino acids with carbonyl components. J Dairy Sci 72, 604-613 
Klostermeyer H, Krause I (1992) Kriterien zur Charakterisierung von Käsesorten. Molk Ztg Welt Milch $46,174-177$

Langsrud T, Reinbold GW, Hammond EG (1977) Proline production by Propionibacterium shermanii p59. J Dairy Sci 60, 16-23

Lavanchy P, Bühlmann C (1983) Valeurs normales de certains paramètres importants du métabolisme pour des fromages fabriqués en Suisse. Schweiz Milchw Forsch 12, 3-12

Lavanchy P, Sieber R (1993) Proteolyse in verschiedenen Hart- und Halbhartkäsen. I. Freie Aminosäuren. Schweiz Milchw Forsch 22, 59-64

Lavanchy P, Bühlmann C, Blanc B (1979) Vergleichende Untersuchungen in Emmentalerkäsen mit und ohne Nachgärung. II. Aminosäuren. Schweiz Milchw Forsch 8, 9-14

Leuthardt F (1977) Intermediär Stoffwechsel Walter de Gruyter, Berlin

Linden G, Chamba J-F (1994) La typicité des fromages : une réalite, un objectif. Sci Aliments 14, 573-580

Moore S, Stein WH (1951) Chromatography of amino acids on sulfonated polystyrene resins. $J$ Biol Chem $192,663-681$

Polo C, Ramos M (1985) Free amino acids by highperformance liquid chromatography and peptides by gel electrophoresis in Mahon cheese during ripening, Food Chem 16, 85-96

Rank TC, Grappin R, Olson NF (1985) Secondary proteolysis of cheese during proteolysis. J Dairy Sci $68,801-805$

Resmini P, Pellegrino L, Pazzaglia C, Hogenboom JA (1985) Gli amminoacidi liberi nella tipizzazione del formaggio Parmigiano-Reggiano ed in particolare del prodotto grattugiato. Sci Tec LattCasearia 36, 557-592

Resmini P, Hogenboom J A, Pazzaglia C, Pellegrino L (1993) Gli amminoacidi liberi nella caratterizzazione analitica del formaggio Grana Padano. Sci Tec Latt-Casearia 44, 7-19

Schär H, Glättli H, Nick B, Sieber R, Steiger G (1992) Untersuchungen über den Reifungsverlauf guter Walliser Raclettekäse. Schweiz Milchw Forsch 21, 63-69

Schuster R (1988) Determination of amino acids in biological, pharmaceutical, plant and food samples by automated precolumn derivatization and high-performance liquid chromatography. J Chromatogr 431, 271-284
Sollberger H, Glättli H, Nick B, Rüegg M, Sieber R, Steiger G (1992) Untersuchungen über den Reifungsverlauf guter Sbrinzkäse. Schweiz Milchw Forsch 20, 63-69

Steffen C, Bühlmann C, Schnider J, Schär H, Rentsch F (1979) Vergleichende Untersuchungen in Emmentalerkäsen mit und ohne Nachgärung. I. Probenerhebung, statistische Auswertung und Fabrikationsdaten. Schweiz Milchw Forsch 8 , 3-8

Steffen C, Glättli H, Steiger G, Flückiger E, Bühlmann C, Lavanchy P, Nick B (1980) Vergleichende Untersuchungen von Greyerzerkäsen mit und ohne Nachgärung. I. Bakteriologische, biochemische, chemische und rheologische Untersuchungen. Schweiz Milchw Forsch 9, 19-27

Steffen C, Glättli H, Steiger G, Flückiger E, Bühlmann C, Lavanchy P, Nick B, Schnider J (1981a) Vergleichende Untersuchungen von Sbrinzkäsen mit und ohne Nachgärung. I. Bakteriologische, biochemische, chemische und rheologische Untersuchungen. Schweiz Milchw Forsch 10, 3-11

Steffen C, Glättli H, Steiger G, Flückiger E, Bühlmann C, Lavanchy P, Nick B, Schnider J, Rentsch F (1981b) Vergleichende Untersuchungen von Appenzellerkäsen mit und ohne Nachgärung (bakteriologische, biochemische, chemische und rheologische Analysen). Schweiz Milchw Forsch 10 , $51-58$

Steffen C, Glättli H, Steiger G, Flückiger E, Rüegg M, Bühlmann C, Lavanchy P, Nick B, Schnider J, Rentsch F (1982) Vergleichende Untersuchungen von Rohmilchtilsiterkäsen mit und ohne Nachgärung. Schweiz Milchw Forsch 11, 51-61

Steffen C, Rentsch F, Nick B, Steiger G, Sieber R, Glättli H, Eberhard P (1992) Reifungsverlauf in qualitativ gutem Greyerzer. Landwirtsch Schweiz $5,209-215$

Steffen C, Schär H, Eberhard P, Glättli H, Nick B, Rentsch F, Steiger G, Sieber R (1993a) Untersuchungen über den Reifungsverlauf von qualitativ gutem Käse: Appenzeller. Schweiz Milchw Forsch 22, 39-45

Steffen C, Schär H, Eberhard P, Glättli H, Nick B, Rentsch F, Steiger G, Sieber R (1993b) Untersuchungen über den Reifungsverlauf von qualitativ gutem Käse: Tilsiter aus Rohmilch. Schweiz Milchw Forsch 22, 46-51

SYSTAT (1992) SYSTAT for Windows. SYSTAT Inc, Evanston, IL, version 5.0 edn

Urbach G (1993) Relations between cheese flavour and chemical composition. Int Dairy J 3, 389-422 